\title{
MIKE KÁROLY
}

\section{Merre vezessen a magyar kapitalizmus útja? Látkép Ronald Coase világítótornyából}

A tanulmány - amely Coase és az új intézményi közgazdaságtan alapján keresi a címbeli kérdésre adható választ - a kapitalizmus alapvető interakciós formájaként a kölcsönösen elönyös cserét azonosítja, amely az emberi együttmüködés megnyilvánulása. A gazdasági fejlődés feltétele e kooperáció költségeit csökkentő társadalmi játékszabályok, intézmények kialakítása. A jól müködő kapitalizmus intézményi rendje sürü és sokrétü, a részleteit tekintve időben és térben igen változó, jelentős részben nem állami, hanem magáneredetü. Ez a rend nem tervezhető meg, és jelenlegi tudásunk alapján nem is érthető meg konzisztens, összefüggő rendszerként. A magyar gazdaság fejlödési célját ezért nem lehet nemzetgazdasági szintủ rendszerként vagy modellként megfogalmazni. A tényleges feladat az intézményi rend középszintü elemeinek fokozatos, kísérletező változtatása, figyelembe véve a már létezö intézményi környezet történetileg adott, helyhez és időhöz kötött sajátosságait. De az intézményi „barkácsolásnak” mindvégig szem elött kell tartania a kapitalizmus alapelvét: az önkéntes, kölcsönösen elönyös tranzakciók támogatását. ${ }^{*}$ Journal of Economic Literature (JEL) kód: K10, P10, P20, L14, 017.

Milyen gazdasági rend hozhat prosperitást Magyarország számára, és mi az az út, amely ehhez a rendhez elvezet? A rendszerváltás idején a közgazdaságtanban és a közgondolkodásban is lényegében konszenzus volt arról, hogy piacgazdaságot kell megteremteni, Nyugat-Európa mintájára, amelyhez az ország csatlakozni, felzárkózni kívánt (Szamuely-Csaba [1998], Kornai [2000], Murrell [2005]). Maga a rendszervált(oz)ás kifejezés is azt tartalmazza, hogy a meglévő helyett egy másik jól körvonalazható rendszert kívánunk meghonosítani (Bod [2011]). Egyre többen gondolják úgy, hogy ez nem sikerült: az utóbbi öt-tíz évet a kezdeti sikereket követő hanyatlás követte (Muraközy [2008]), a felzárkózás - ahogy a történelemben korábban - most sem sikerült (Csaba [2011]), sőt

* A kutatómunkát az MTA Bolyai posztdoktori ösztöndíja és az OTKA posztdoktori kutatási ösztöndíja (PD 113072) támogatta. A szerző köszönetét fejezi ki a 2015. szeptember 15-i Hétfa Mủhely résztvevőinek, továbbá Szalai Ákosnak, Rosta Miklósnak és a cikk lektorának értékes észrevételeikért.

Mike Károly, a BCE Közgazdálkodás és Közpolitika Tanszékének egyetemi docense, a Hétfa Kutatóintézet tudományos fömunkatársa (e-mail: karoly.mike@uni-corvinus.hu).

A kézirat első változata 2015. november 18-án érkezett szerkesztőségünkbe.

DOI: http://dx.doi.org/10.18414/KSZ.2016.6.597 
kifejezetten elkanyarodtunk a nyugati modelltől (Csillag-Szelényi [2015]). Akik nem osztják ezt a negatív értékelést, azok is a kapitalizmus sajátos, félperiferikus változatát látják kibontakozni a térségben, így Magyarországon is (például Nölke-Vliegenthart [2009], Bohle-Greskovits [2012]). Mindenesetre a magyar lakosság nagy része kiábrándult a kapitalizmusnak abból a formájából, amelyet megismert: míg 1991-ben 80 százalékuk tartotta jó ötletnek a „szabad piacokra” való áttérést, 2009-ben már a többségük - a posztszovjet régióban is kirívó módon - ellenkező véleményen volt ( $P E W$ [2009] 6. o.). A csalódottságot tükrözi annak a 2010 utáni politikai retorikának a népszerüsége is, amely a Nyugattól való elfordulást és a Kelet felé „nyitást” feszegeti, illetve valamiféle sajátos „magyar út” szükségességét fogalmazza meg.

A korhangulat mögött megbúvó kérdést érdemes komolyan venni. Ha a nyugat-európai eszmény megvalósíthatósága a jövő ködébe vész, mi lehet az a prosperitást hozó gazdasági rend, amelyet a magyar politikai közösség belátható időn belül elérhető célként tüzhet ki maga elé? Nagy a kísértés, hogy a magyar gazdaság fejlődési célját egy jól megragadható rendszerszintű modellként fogalmazzuk meg - legyen szó „nyugati” vagy „,keleti”, netán „nyugat-”, vagy „,kelet-közép-európai”, esetleg „unikálisan magyar" modellekről. Amellett igyekszünk érvelni, hogy érdemes kritikusan viszonyulnunk az ilyen javaslatokhoz. Csak úgy kerülhetünk közelebb egy megalapozott válaszhoz, ha leásunk az alapokig: megvizsgáljuk a modern kapitalizmus természetét. Mi az, ami közös a sok szempontból nagyon különböző kapitalista gazdaságokban, mi az, amiben különböznek, s miből fakadnak e különbségek? Elsőként erre teszünk kísérletet Ronald Coase és az őt követő „új intézményi” közgazdászok munkássága alapján. Az így felvázolt elméleti keretben próbáljuk meg azonosítani, hogyan fogalmazható meg értelmesen a magyar gazdaság fejlődésének célja, és melyek azok a változások, amelyek közelebb vihetnek e célhoz. ${ }^{1}$

Az értelmezési keret mindig nagymértékben befolyásolja a normatív javaslatokat. A következőkben felvázolt kapitalizmusértelmezés hangsúlyozottan csak egy, korunk gazdasági életének sok lehetséges ,látképe” közül. Amint Monet is számos képet festett a roueni katedrálisról, amelyek az összetett struktúra más-más jegyeit emelik ki, úgy a gazdaság komplex rendjéről is különböző koherens értelmezések adhatók. ${ }^{2} \mathrm{~A}$ tanulmány remélt hatása a vitára ingerlés, a rivális képek „felfestésére” késztetés.

Ronald Coase életműve korántsem természetes választás, ha valaki a modern gazdaság egészére vonatkozó értelmezési keret felvázolására törekszik. Leghíresebb írásai a gazdaság fontos, de mégis csak részletkérdéseiröl - a Coase [1937/2004] a vállalatokról és a Coase [1960/2004] az externáliákról - szólnak. Az életmüvének

\footnotetext{
${ }^{1}$ Magyar nyelven fontos elözmény a Közjó és Kapitalizmus Intézet 2009-2011 közötti kezdeményezése, amely kifejezetten az új intézményi közgazdaságtan ihlette normatív keretben vizsgálta a „magyar kapitalizmus állapotát” (Szalai [2009], [2010], [2011], Szepesi [2009]). A jogrend és a társadalmi normák gazdasági hatásainak vizsgálata ugyan fontos témája a magyar társadalomtudományos irodalomnak, de jellemzően más, szociologizáló vagy makrogazdasági elméleti keretben. Lásd például Kornai és szerzőtársai [2006], Csaba [2006], Hámori és szerzőtársai [2007], Tóth [2009], Muraközy [2012]. Az agrárgazdaságtan olyan terület, ahol fokozottan jelen van az új intézményi megközelítés (lásd például Fertö és szerzőtársai [2012] hivatkozásait).

${ }^{2}$ A Monet-párhuzam a Calabresi-Melamed [1972] cikkből származik, amely amellett érvelt, hogy a jogrend közgazdasági elemzése egy, a jogrend vizsgálatának lehetséges nézőpontjai közül.
} 
javát bemutató kötetének címe - A vállalat, a piac és a jog (Coase [1988/2004]) - is jól jelzi, hogy érdeklődésének középpontjában nem a gazdasági rendszerek, hanem azok egyes alkotóelemei álltak.

Ez igaz az őt követő „új intézményi” közgazdászokra is, akiknek az elemzései a gazdasági jelenségek „középszintjén” mozognak: a gazdasági élet játékszabályait vizsgálják, az egyéni döntések és a komplex makrogazdasági jelenségek között félúton (North [1990], Ménard-Shirley [2005], Brousseau-Glachant [2008]). Ráadásul Coase még az általa vizsgált intézményekről sem dolgozott ki átfogó elméleteket, tanulmányai jellemzően megmaradtak a problémafelvetés és a vázlatos válaszkísérlet szintjén. Amint a Nobel-díj átvételekor tartott előadásában fogalmazott, nem füződik a nevéhez innováció a „magas elmélet” terén (Coase [1992] 713 o.). Követői az elméletalkotásban sokat léptek elöre, egységes elméleti rendszert azonban nem alkottak. Amint Williamson fogalmazott, „az új intézményi közgazdaságtan eszmék fortyogó üstje. Nemcsak számos intézményi kutatási program van folyamatban, hanem azokon belül is versengő eszméket látunk." (Williamson [2000] 610. o.) Ez utóbbi is oka annak, hogy ennek a - Coase mellett más forrásokból is táplálkozó - irodalomnak a rendszerező áttekintése helyett szűkebben Coase eszméire és azok kibontakozására helyezzük a hangsúlyt ezen az irodalmon belül.

Az átfogó, rendszerszintủ elmélet hiánya látszólag komoly érv az ellen, hogy éppen Coase-ból kiindulva próbáljuk megérteni a kapitalizmus egészét. Amint azonban igyekszünk kifejteni, a tudatos tartózkodás Coase részéről attól, hogy a gazdaság egészét rendszerként elemezze, megközelítésének nem hiányossága, hanem éppen erőssége. A feladatot ugyanakkor sajátosan megnehezíti, hogy Coase és más szerzők írásaiból nem egyszerủen ismertetni, hanem rekonstruálni kell a gazdaságnak azt a fent említett „látképét”, amely a részletek elemzéséből kibontakozik. Ez a citált művek értelmezését a kritikus irodalomelemzés müfajánál óhatatlanul személyesebbé teszi.

Ahhoz, hogy Coase-t szellemi iránytünek válasszuk, elégséges indokkal szolgál az általa útnak indított új intézményi közgazdaságtan (és a tőle részben elkülönülő joggazdaságtan) rendkívüli termékenysége, mind a fejlett gazdaságok belső müködésének, mind a gazdasági fejlődés feltételeinek jobb megértésében. De fontos adalék az is, hogy Coase gondolatai és megközelítése kivételesen nagy hatást gyakoroltak Kínában, ahol hosszú élete vége felé a legünnepeltebb közgazdászok közé tartozott (Mike [2014]). Persze tévedhetnek a kínai közgazdászok, de a példájuk annyit minden bizonnyal megér, hogy Magyarországon is komolyabban elgondolkozzunk a szerző munkásságának relevanciáján.

\section{A kapitalizmus mint a kooperáció rendje}

Coase hírnevét (és Nobel-díját) két folyóiratcikknek köszönheti. Az első A vállalat természete címü, 1937-ben megjelent írása, amelynek központi gondolata egy egyszerü, ám annál eredetibb megfigyelés volt (Coase [1937/2004]). A piacgazdaságban egyszerre van jelen az erőforrások allokációjának kétfajta mechanizmusa: a versenyen alapuló árkoordináció és a versenyt felszámoló központi utasítás. Az előbbi a piacokon zajlik, míg az utóbbi 
keretét a vállalatok képezik, e két szerveződési mód együtt alkot hatékony rendszert. Az árak felderítése, megállapítása, alku révén való elfogadása ugyanis olyan költségekkel járhat, amelyet rendszeres tranzakciók esetén nem mindig érdemes felvállalni. Érdemes lehet egy átalányárat, átalánybért megszabni, amelyért az egyik fél hajlandó egyszerüen a másik fél utasításait követni. Lényegében ezért jönnek létre vállalatok. A gazdálkodás egyik kulcskérdése pedig az, hogy milyen tranzakciót lehet kisebb költséggel a piacon, vagyis a vállalkozások között, s melyeket azokon belül megszervezni.

Mihelyt beemeljük a vállalat belső világát a közgazdasági elméletbe, világossá válik, hogy a kapitalizmus müködésének alaplogikája nem ragadható meg a verseny vagy az ármechanizmus fogalmaival. ${ }^{3}$ Amint Coase nyomán Williamson [1975] kifejtette, a szabad verseny körülményei között a termelés szereplői szándékosan számolják fel átmenetileg a versenyt, emelik ki kapcsolataikat a verseny közegéböl, méghozzá úgy, hogy ezzel növelik, nem pedig csökkentik a termelés hatékonyságát. Ráadásul éppen azokban a gazdaságokban a legmélyebb a vállalkozások, gazdasági társaságok hagyománya, ahol legkiterjedtebb, legélénkebb a piaci verseny (Kuran [2012]). A kapitalizmusnak tehát ugyanúgy lényegi eleme a spontán, versengő árkoordináció, mint az ettől való eltérés. Ami közös az ármechanizmusban és a vállalati hierarchiában, hogy mindkettö az önkéntes és kölcsönösen előnyös, kooperatív csere megnyilvánulása. A különbség a kooperáció megszervezésének módja, ami az egyikben két független piaci fél közötti szerződésén, a másikban a hierarchia szerinti munkaszerződésen alapul.

Coase másik híres cikke - A társadalmi költség problémája - az „üzleti vállalkozások azon cselekedeteit vizsgálja, amelyeknek másokra nézve káros hatásuk van" (Coase [1960/2004] 139. o.). Coase Pigou megközelítését kritizálta, amely a külső gazdasági hatást (externáliát) az ármechanizmus kudarcaként azonosította. Ha például egy vállalat szabadon kárt okozhat másoknak - mondjuk környezetszennyezés révén -, a másik kárát nem fogja beépíteni a költségfüggvényébe. A vállalati termelés érzékelt költsége így elmarad a valós társadalmi költségtől, ami túl magas termelési szinthez és túl alacsony árhoz vezet a piaci egyensúlyban. Coase rámutatott, hogy az érvelés hibás: abból, hogy a törvény megengedi a szennyezést, nem következik, hogy a vállalat annak másra gyakorolt hatásait ne venné figyelembe. Ha lehetösége van a másik féllel megállapodni, és tőle kompenzációt kapni a szennyezés megelözéséért vagy csökkentéséért, akkor ezt igenis megéri neki figyelembe venni. A gazdasági hatás csak akkor marad „külsö”, ha a megegyezés várható költségei meghaladják annak várható hasznát. Más szóval, az externália mindig a kooperáció kudarcából származik. Ennek megfelelően az elsődleges megoldását is a kooperáció költségeinek csökkentése jelentheti, és ha az nem lehetséges, akkor kell más társadalmi eszközhöz fordulni.

Azt, hogy a kooperáció logikája központi helyet foglal el Coase gondolkodásában, egy harmadik, kevésbé ismert cikke is bizonyítja. A világítótorony a közgazdaságtanban (Coase [1974/2004]) annak cáfolatára hoz fel egy történelmi példát, hogy a világítótornyok szolgáltatását mint „közjószágot” magánúton nem lehet előállítani. A részletes esettanulmány szerint a 19. századi Angliában a szolgáltatást élvező hajóktól a brit kikötők szedtek díjat a világítótornyok használata után, amelyet azután a

\footnotetext{
${ }^{3}$ Az ebben a bekezdésben adott értelmezés vázlatát lásd Mike [2014].
} 
tornyot üzemeltető magántulajdonosoknak adtak tovább. A finanszírozás rendszere így lényegében „piaci” alapú volt: magánvállalkozók közötti önkéntes szerződéseken alapult. A történeti eset értelmezése, mint mindig, viták tárgyát képezi. Az okfejtés elsődleges hozadéka azonban itt is elméleti: az externáliához hasonlóan a közjószág is akkor jelentkezik „piackudarcként”, ha az érintett felek közötti önkéntes kooperációt a magas tranzakciós költségek megakadályozzák.

Coase elemzéseiben visszatérő motívum tehát, hogy a jól működő gazdaság alapja a magánszemélyek és szervezeteik közötti önkéntes kooperáció. Bár idézett cikkeiben nem fejti ki, más műveiben világossá teszi, hogy ez korántsem véletlen, hanem tudatos szemlélet következménye. Mivel az általa bírált szerzők is Adam Smithre vezetik viszsza elméleteiket, meglepő lehet, hogy Coase is Smithre hivatkozik, amikor a saját megközelítését kívánja alátámasztani. Schumpeterrel egyetértve hangsúlyozza, hogy a skót gondolkodó igazi újítása az volt, hogy a munkamegosztást és a belőle fakadó kooperációs szükségletet tette meg elemzése sarokkövévé. A „nemzetek gazdagságának” zálogát pedig a kölcsönösen előnyös cserék mint az önkéntes együttműködés megnyilvánulásainak rendszerében, a „kereskedő társadalom” kiépülésében látta.

A közgazdaságtan központi kérdése eszerint a következő: „Hogyan valósítható meg emberek óriási tömegeinek együttmüködése szerte a világ országaiban, ami egy mégoly szerény életszínvonalnak is feltétele?” (Coase [1977] 313. o.) A 20. században nem Coase volt az egyedüli, aki visszatért a csere mint együttmüködési forma központi jelentőségéhez. Buchanan [1964] és Hayek [1982] is „katallaxisként”, vagyis cserék rendszereként határozta meg a piacgazdaságot. Ugyanakkor ő volt az első, aki - Smithen túllépve, és eltérően Buchanantől és Hayektől - azt javasolta, hogy a közgazdaságtan a kooperáció költségeire összpontosítson. A modern gazdaság problémáit a „tranzakciós költségek” problémáiként azonosítsa.

A kapitalizmus vagy kereskedő társadalom fundamentumát képező interakció tehát Coase szerint - ma ugyanúgy, mint Smith idejében - az önkéntes, kölcsönösen elönyös csere mint az emberek közötti kooperáció megnyilvánulása. A növekvő jólét forrása a cserék körének bövülése és a cserékben felajánlott szolgáltatások egyre értékesebbé válása. E kedvező folyamatok feltétele pedig a kooperáció akadályainak felszámolása, költségeinek csökkentése. ${ }^{4} \mathrm{~A}$ verseny és az ármechanizmus fontos kísérö jelenségei a cserének, de másodlagosak hozzá képest. A piaci verseny a kooperáció szabadságából fakad: a kooperatív ajánlatokat tevők versengése. A piaci egyensúlyi árak koordinálják az ajánlatokat és megkönnyítik a megegyezést.

\section{A kapitalizmus mint a kooperációt támogató intézményi rend}

Coase javaslata, hogy a közgazdaságtan a kooperáció költségeire összpontosítson, terméketlen maradt volna, ha nem teszi világossá, mitöl függ e költségek nagysága. Az alapgondolat már A vállalat természete címủ írásában megjelenik (Coase

\footnotetext{
${ }^{4}$ A magyar gazdaság értékelésére ezzel egybevágó normatív keretet javasolt Szalai-Szepesi [2009], és alkalmazott Szepesi [2009], Szalai [2010], [2011].
} 
[1937/2004]). Először is a tranzakció jellemzőitől - például a szolgáltatás mérhetőségétől, egyediségétől, gyakoriságától - függ, hogy miért és mennyire nehéz a két fél számára együttműködni (megállapodni, szerződni és a szerződést betartatni). Másodszor pedig a cserekapcsolat kialakított játékszabályai befolyásolják, hogy a kooperálás nehézségeit mennyire sikerül leküzdeni. A feladat tehát egyrészt, amint később Williamson világossá tette, a tranzakciótípusok és a tranzakciókat irányító játékszabályok összehangolása (Williamson [1985] 68-84. o.). Például egy vállalat esetében a szabványosított áruk piaci szerződések keretében való megvásárlása, illetve az egyedi igényekhez szabott, nehezen mérhető alkatrészek belső, hierarchikus viszonyban történő elóállítása.

Továbbá, a játékszabályokat úgy kell kialakítani, hogy azok csökkentsék az együttmüködés költségeit. A szükebb szabályokat a felek fektetik le, amikor a szerződéses kapcsolatuk jellegéről és azon belül is a szerződésük egyes kitételeiről döntenek. A szerződéskötés pedig tágabb szabályrendszerbe illeszkedik: a polgári jog, a hatósági szabályozások, az üzleti élet normáinak rendszerébe. Ezen alapul az új intézményi közgazdaságtan programja: a cél annak megértése, hogy az említett társadalmi játékszabályok, azaz „az emberek közötti interakciót meghatározó, az emberek által kialakított korlátok”, más szóval „intézmények” hogyan befolyásolják az emberek közötti együttműködés sikerét (North [1990] 13. o.).

Ha igaz, hogy a kapitalizmus alapvető interakciója a cserekapcsolatokban megvalósuló kooperáció, akkor alapvető intézményei azok, amelyek lehetővé teszik, támogatják ezt a kooperációt. Coase tömören így fogalmaz: „A piacok a csere lebonyolítására létrejött intézmények, vagyis azért léteznek, mert a csere tranzakcióival járó költségek általuk csökkenhetnek" (Coase [1988/2004] 20. o.). Ha egy piac - például egy „tökéletes versenyhez” közel álló tőzsde - jól müködik, az csak azért lehetséges, mert az eladók és a vevők együttmüködésének költségeit egy összetett (informális normákban, üzleti gyakorlatokban, jogrendben, hatósági intézkedésekben stb. testet öltő) szabályrendszer minimálisra csökkenti. ${ }^{5} \mathrm{Ha}$ a „nemzetek gazdagságának” titkát keressük a modern korban, akkor ezekre az intézményekre kell összpontosítanunk. Ha normatív ideálként akarjuk megfogalmazni a kapitalizmus vagy kereskedő társadalom lényegét, azt mondhatjuk, hogy az az intézményi rend, amely a cserekapcsolatok formáját öltö együttmüködés költségeit a lehetö legkisebbre csökkenti.

\section{Az intézményi rend alapvető jellemzői}

Hogyan épül fel a kapitalizmus intézményi rendje, mik az alkotóelemei? Coase nem adott erre kimerítő választ, de írásaival rámutatott, hogy az intézményi rend a tulajdonjogokat és szerződéseket támogató játékszabályok együtteseként ragadható meg. A tulajdonjogok kijelölik, kinek milyen döntési jogkörei vannak a különböző eröforrásokra vonatkozóan (Coase [1960/2004], Demsetz [1967], Barzel [1997]). Világossá teszik, ki mit és kivel cserélhet el. Ehhez szükség van többek között a tulajdonjogok

\footnotetext{
${ }^{5}$ A piac intézményként történő lehetséges felfogásairól lásd Kapás [2003].
} 
tartalmának, határainak világos kijelölésére (Demsetz [1967]), mind a nem szándékolt - például baleset jellegü - konfliktusok (Calabresi-Melamed [1972]), mind pedig a tudatos károkozás, erőszakos redisztribúció szabályozására, történjen az akár magánszemélyek, akár a kormányzat részéről (North-Weingast [1989], Greif [2005]). A szerződések a döntési jogokkal rendelkezők - vagyis a tulajdonosok - közötti együttmüködés kereteit, mechanizmusait biztosítják (Coase [1937/2004], Cheung [1983], Williamson [1985]). Egyrészt koordinálják a potenciálisan cserekapcsolatra lépő felek döntéseit - segítenek megtalálni a megfelelő cserepartnert, árat, illetve szerződéses feltételeket. Másrészt elősegítik a szerződéses ígéretek kikényszerítését és ezáltal a felek közötti bizalom létrejöttét (Hermalin-Katz-Craswell [2007]).

A tulajdonra és a szerződésre magától értetődően hat a jogrend, azon belül is elsősorban a polgári jog. Coase a Nobel-dij átvételekor tartott összegzésében kitért arra, hogy a hatósági szabályozás mellett - amely természetesen sok esetben szintén fontos - igyekezett e felé az alapvetö intézményi terület felé fordítani a közgazdászok figyelmét (Coase [1992]). ${ }^{6}$ A formális jog jelentősége abból fakad, hogy a széles körü munkamegosztáson alapuló gazdaságban lehetővé teszi az ismeretlenek közötti kooperációt is, vagy ahogyan újabban Avner Greif fogalmazott: a személytelen cserét (Greif [2006] 309-310. o.). A formális jogrend hátterében pedig ott húzódnak az azt definiáló és érvényesítő szervezetek, amelyek maguk is sajátos játékszabályok között müködnek (Coase [1959], [1974/2004]). Ezen a ponton a coase-i kutatási program összeér a közösségi döntések elméletével, amely a politika és a bürokratikus döntéshozatal „alkotmányos” szabályaiból fakadó ösztönzők szerepét hangsúlyozza (Brennan-Buchanan [1985]).

A vállalat természete és a belőle kibontakozó irodalom azt is világossá tette, hogy nemcsak a formális jog "fölötti”, politikai szabályok fontosak, hanem az az „alattiak” is, amelyeket a magánszereplök alakítanak ki. A szerződések részleteit, a hosszú távú üzleti kapcsolatok irányítási struktúráit, a vállalatok belső működési szabályait nem a jog írja elö, hanem az érintettek alkotják meg (Goldberg [1980], Williamson [1985]). Mára óriásira duzzadt empirikus irodalom bizonyítja, hogy minden virágzó, modern gazdaságnak nélkülözhetetlen elemei a jogilag ki nem kényszeríthető szerződések, informális normák, üzleti célú és egyéb közösségek, hálózatok, önszabályozó testületek is (Ménard-Shirley [2005], Brousseau-Glachant [2008]). Az együttmüködés jogibürokratikus személytelen és informális személyes formái, illetve az ezeket támogató intézmények együtt vannak jelen benne.

A kapitalizmus intézményi rendje tehát sürü és sokrétü. Téves az a nézet, amely egyetlen forrásból, a törvényhozás vagy a kormányzás aktusaiból eredezteti a gazdaság játékszabályait. Helyesebb policentrikus, vagyis többközpontú rendről beszélni (Ostrom [2005]): az „állam” absztrakt keretein belül és azon kívül is számos olyan személy vagy szervezet van, amely részt vesz a szabályrendszer kialakításában és fenntartásában. Ennek mélyen gyökerező oka, hogy a megfelelő intézmények létrehozása maga is kooperációs feladat, amelynek tranzakciós költségei

\footnotetext{
${ }^{6}$ Részben coase-i alapokon fejlödött ki a joggazdaságtan (law and economics) irányzata (ParisiRowley [2005]. Magyarul lásd Cooter-Ulen [2005], Szalai [2013].
} 
vannak (Bates [1988]). A játékszabályok megalkotóinak és érvényesítőinek megfelelő információval és motivációval kell rendelkezniük. Hozzá kell tennünk, hogy a szabályok jelentős része nem is tudatos döntés eredménye, hanem nem szándékolt, evolutív módon jön létre (Greif [2005], Boettke-Coyne-Leeson [2008]). A sokrétüség és a többközpontúság velejárója az intézmények bámulatos sokfélesége (Ostrom [2005]), nemcsak az egyes országok között - ami mindenki számára nyilvánvaló -, hanem azokon belül is áru- és szolgáltatástípusok, piacok, ágazatok, üzleti célú és egyéb közösségek, hálózatok esetében is.

\section{A rendszerszemlélet elvetése}

A tudományos elemzés természetesen törekszik a minél letisztultabb és általánosabb elméletek kialakítására, így érthető, ha egy közgazdászt elkedvetlenítenek az intézményi rend összetettségét, bonyolultságát hangsúlyozó állítások. A közgazdaságtanban a makroökonómia (Keynes), az általános egyensúlyelmélet (Arrow-Debreu) és további a Kornai [1999] által a rendszerparadigma körébe sorolt - számos nagy elmélet (Marx, Mises, Hayek, Polányi Károly, Schumpeter, Eucken) egyaránt a nemzetgazdaságok egészének működését próbálta megragadni, a leegyszerüsítés különböző módszereivel és fokán. Adódik a kihívás, hogy a kapitalizmus sokféle intézményére vonatkozó tudást is egy átfogó, rendszerszintű elméletben összegezzük, amely kiemeli az igazán lényeges, és figyelmen kívül hagyja a másodlagos elemeket, összefüggéseket.

Coase azonban elutasította ezt, méghozzá két okból. Egyrészt úgy vélte, hogy a közgazdászok egyelöre igen keveset tudnak a nemzetgazdaságoknál jóval kevésbé összetett intézményi jelenségekről is, mint amilyen például egy piac vagy ágazat játékszabályrendszere. Jóslata szerint legalább száz évre és egy újabb Adam Smith formátumú gondolkodóra lesz szükség egy elfogadható szintézishez (Coase [1997]). Kétkedését igazolni látszik az új intézményi iskolába sorolható szerzőknek adott 2009-es Nobeldíj is. Oliver Williamson és Elinor Ostrom egy-egy rendkívül fontos, de szük intézményi problémának - a vállalatok, illetve a közösen használt erőforrások irányításának - általános érvényű elméletét dolgozta ki. Ha az intézményi közgazdaságtan legújabb kézikönyveit vesszük kézbe (Ménard-Shirley [2005], Brousseau-Glachant [2008]), azokban szintén a középszintű elemzések vannak túlsúlyban.

Másrészt Coase erősen kételkedett egy rendszerszintü elmélet gyakorlati hasznában. Hayek [1991] rámutatott, hogy „végzetes önhittség” volt a szocializmus hívei részéről azt képzelni, hogy elég tudásuk van ahhoz, hogy a gazdasági folyamatok részleteit megtervezzék. Legutolsó, Kína felemelkedéséről írott társszerzős könyvében Coase ezt az érvelést kiterjesztette az intézményekre vonatkozó tudásra: „Aki hisz abban, hogy egy piacgazdaságot racionálisan meg lehet tervezni, az - Hayek szavaival - a konstruktív racionalizmus "végzetes önhittségének« hibájába esik." (CoaseWang [2012] 155. o.) „A terv- és a piacgazdaság különbségei mélyen eltérő mentalitást és attitüdöt tükröznek [...] Egy piacgazdaság két mély ismeretelméleti elkötelezödést feltételez: a tudatlanság elfogadását és a bizonytalanság tolerálását" (uo. 18. o.) - nemcsak a gazdasági szereplök egyes döntéseit illetően, hanem az ezeket mederbe terelö 
intézményekre vonatkozóan is. Kína sikerét jelentős részben az intézményi kísérletezésnek, „improvizációnak és barkácsolásnak” tulajdonította, $s$ ami létrejött, abban - a Kínáról szóló irodalom nagyobb részével (például Sachs-Woo [2001] Xu [2011], Székely-Doby [2014]) szemben - nem a politika által vezérelt reformfolyamat tudatosan elért gyümölcsét, hanem „emberi cselekvés, de nem emberi terv eredményeit” látta (Coase-Wang [2012] 154. o.).

A feladat egy fejlődő ország számára így nem lehet a piacgazdaság megteremtése, de még csak annak valamely alváltozatának, modelljének megvalósítása sem. A kapitalizmus eredeti, természetes környezetében, az európai civilizációban sem tervszerüen, hanem hosszú, spontán, kudarcokkal teli intézményfejlődés eredményeként alakult ki. ${ }^{8} \mathrm{Ha}$ le is lehet rövidíteni az utat intézmények részleges átvételével (aminek korlátairól lásd később), a kísérletezés és a „barkácsolás” türelmes aprómunkáját megtakarítani, s a szóban forgó út kiszámíthatatlanságát felszámolni nem lehet. Ha ki is alakul egy nemzetgazdasági „rendszer” vagy „modell”, a melyet utólag megérthetünk, elöre konzisztensen eltervezni nem tudjuk. Egy Magyarországhoz hasonló ország számára a valódi kihívás nem „gazdasági rendszerek” vagy nemzetgazdasági szintü „modellek” közötti választás. Ez nem jelenti azt, hogy az intézményi fejlődésnek nem kellene irányt szabni. A kapitalizmus rendje egy világos intézményi alapelven: az önkéntes, kölcsönös elönyös csere mint kooperációs forma támogatásán alapul. A tényleges feladat ennek az elvnek a konkretizálása az intézményi rend elemeinek fokozatos, kísérletező változtatásával, figyelembe véve a már létező intézményi környezet történetileg adott, helyhez és időhöz kötött sajátosságait.

\section{Kitérő: a rendszerváltás szellemi hagyatékának felülvizsgálata}

Coase-Wang [2012] lényegében azt a meglepő állítást fogalmazza meg, hogy a kapitalizmus intézményi rendjéhez jobban illik az a graduális intézményépítési logika, amelyet Kína követ, mint a kelet-európai rendszerváltás big bangje. Ennek kapcsán ma nem az az érdekes kérdés, hogy a gazdasági rendszerváltást jól vagy rosszul valósítottuk-e meg. Ha lehetett volna az intézményi rend átalakítását bizonyos pontokon másképpen véghez vinni, az sem változtatott volna azon a történelmi helyzeten, amely elkerülhetetlenné tette, hogy gyorsan és nagyon sok elemében változzon az intézményi rend. Ma sokkal fontosabb annak megértése, hogy az intézményi változás radikalitása és rendszerszerüsége nem a bevezetendő kapitalizmus, hanem a felszámolandó szocializmus sajátosságaiból fakadt. Abból, hogy az ancien régime alapelve a kapitalista intézményi rend szándékos és rendszerszerü megtagadása, felszámolása volt. ${ }^{9}$ Azt mondhatjuk, hogy az intézményi rend átalakítása a tervgazdaság intézményi forradalma volt „visszafelé”. Amit megéltünk, ezért öltötte a rendszerváltás formá-

\footnotetext{
${ }^{7}$ A szerzőpáros Hayektől átvett idézete természetesen a skót Adam Fergusontól származik.

${ }^{8}$ A legújabb új intézményi irodalomból lásd különösen Greif [2006], Hough-Grier [2015].

${ }^{9}$ Természetesen a felszámolás sosem volt, nem is lehetett tökéletes, és a Kádár-rendszer alatt sok lépés történt a kapitalizmus felé. Ugyanakkor a létező szocializmus intézményi rendjét mindvégig áthatotta a kapitalizmussal szembehelyezkedő rendszerszemlélet.
} 
ját. Belülről nézve a kapitalizmus intézményei nem egy racionális elme által konstruált rendszer elemei, hanem sok szereplő sok döntésének szándékolt és nem szándékolt következményeinek eredőjeként jönnek létre (Greif [2005]).

Abban a kérdésfeltevésben, hogy „nyugati” vagy „keleti”, unikálisan „magyar” vagy más („,közép-európai” stb.) modellt valósítsunk-e meg, a rendszerváltáskor (vagy talán még a „kapitalista” és „szocialista” világ szembenállásakor) belénk ivódott rendszerszemlélet jelenik meg. A rendszerben való gondolkodás kétségtelen haszna lehet, hogy segít megérteni a gazdaság különböző intézményei közötti, illetve a gazdaság és a tágabb kulturális-politikai környezet közötti összefüggéseket (Kornai [1999]). Ugyanakkor Coase és az intézményi közgazdaságtan eredményei felhívják a figyelmünket annak veszélyére, hogy ez a szemlélet feleslegesen gúzsba kötheti gondolkodásunkat - ahelyett, hogy segítené, gátolhatja, hogy megtaláljuk a gazdasági fejlődés útját. Ha rendszert kívánunk alkotni abban az értelemben, hogy az intézményi változások végállapotát mint komplex, áttekinthető, megérthető egészet vetítjük magunk elé, akkor többet kívánunk tudni, mint amennyit ténylegesen tudhatunk. Egyúttal szem elől tévesztjük a valódi előrelépéshez szükséges feladatokat: az intézményi rend óvatos, részleges javítását.

Ezt a szemléletet erősíti, hogy a rendszerváltás a kapitalizmus képzetét az intézményi radikalizmussal is összekapcsolta. Bár a piacgazdaság intézményi rendjének sok eleme már a rendszerváltás elött a helyén volt - részben a kommunizmus elötti múlt, részben a Kádár-rendszer fokozatos intézményi átalakulásának eredményeképpen -, a politikai cezúra a kontinuitás helyett a törésre irányította a figyelmet. Igaz ugyan, hogy a piacgazdaságot jellemző innováció, versengés és dinamizmus sokszor az életviszonyok gyors változásához vezet (Berger [1992]), de ettől meg kell különböztetni a teljes intézményi rend gyors bevezetését vagy átalakítását.

Ha a kapitalizmus coase-i értelmezését tartjuk szem előtt, világos, hogy annak nem lényegi jellemzője az intézmények központi utasításra történő gyors megváltoztatása. Sőt annak korlátai nagyon is nyilvánvalók. Az intézményi radikalizmus eszmei összekapcsolása túlélte az állami tulajdon és a központi tervezés gyors felszámolásáról meghozott politikai döntések korát. Történetileg szerencsétlen módon megjelent az Európai Unió „egységes piacához” való csatlakozás során a döbbenetes mértékü joganyag átvételének követelményében (Milhaupt-Pistor [2008] 210. o.). Úgyszintén a kormányzati költségvetés finanszírozásában részt vevő nemzetközi szervezetek (Világbank, IMF) ajánlásaiban, előírásaiban, az elhíresült „washingtoni konszenzusban" és annak újabb kiadásaiban (Rodrik [2006]). Bármit is gondolunk e fejleményekről, fontos fogalmilag tisztáznunk, hogy itt nem a kapitalizmus rendjének lényegi elemeiről, hanem konkrét politikai és bürokratikus szervezetek sajátos döntéseiröl beszélünk, amelyek ezeknek a szervezeteknek a szemléletét és működését tükrözik. ${ }^{10}$ Tarthatjuk ezeket elhibázottnak, miközben a kapitalizmus intézményi rendjét kívánatosnak, és fordítva.

${ }^{10}$ Természetesen az EU-hoz és a nemzetközi szervezetekhez köthető játékszabályok jelentős része nem a kapitalizmusra vonatkozik, hanem például az államigazgatásra vagy a kormányzati költségvetésre, amelyek szabályozása részben független a gazdaság rendjétől. 


\section{Az intézményépítés „tervezési elvei”}

A belátás, hogy az intézményi fejlődés egyedüli lehetséges útja a „barkácsolás”, a közgazdászokat megfosztja a „mindentudó” szakértő szerepétől. A közgazdaságtan tudósa segíthet az intézményépítési kísérletek megkonstruálásában, de a döntéshozókkal együtt követi nyomon azok lefolyását és tanul belölük. Feladatát legnagyobb meggyőző erővel Elinor Ostrom mutatta be (Ostrom [1990], [2005]). Miután tudományos életművét a természeti erőforrások kooperatív hasznosítását biztosító intézmények feltárásának szentelte, összegző munkájában ezt írja: a legritkább esetben müködnek azok az intézményépítési programok, amelyek „valamilyen elöre meghatározott formulára hagyatkoznak [...] ahelyett, hogy az adott környezet sajátosságait megismernék, és lehetővé tennék a résztvevők számára, hogy kísérletezzenek, és tanuljanak a saját tapasztalatukból és másokéból” (Ostrom [2005] 275. o.).

Ostrom a természeti erőforrások sikeres hasznosítását biztosító játékszabályok rendkívüli változatosságát figyelte meg, és arra a következtetésre jutott, hogy lehetetlen egy vagy több játékszabályrendszert követendő példaként megadni. Ugyanakkor több évtizedes kutatómunka eredményeként azonosítani tudott olyan „tervezési elveket” (design principles), amelyek a sikerre vezető, igen eltérő konkrét szabályokban megtestesültek - így például az erőforrás határainak világos definiálását, a használók által élvezett hasznok és viselt költségek arányosságát, a szankciók fokozatos jellegét (uo. 259. o.). Ha a kapitalizmus intézményépítéséhez általában keresünk útmutatást, ilyen konkrétságú és ennyire megalapozott elveket nem tudunk megfogalmazni. Ostrom szemlélete mégis segítségünkre van, ha az intézményi gazdaságtan ezzel kapcsolatban felhalmozott eredményeit próbáljuk áttekinti. Ha magasabb absztrakciós szinten is, de az irodalomban kirajzolódnak olyan általános intézményépítési elvek, amelyek orientálhatják az intézmények „barkácsolását” vagy - Ostrom elegánsabb kifejezésével - „kimunkálását” (crafting).

1. De jure Versus de facto sZabályok MegkÜlönböZtetéSe • A formális, jogi jellegü szabályok általában csak egy elemét képezik annak a játékszabályrendszernek, amellyel egy-egy gazdasági szereplő ténylegesen szembesül. Egyrészt a közerkölcsök, a társadalmi normák, a bevett üzleti gyakorlat, a piaci reputáció gyakran eröteljesebb ösztönzők, amelyek a formális szabály ellen hathatnak (illetve hiányukban a formális szabály erőtlen marad). Például a formális tulajdonjogokat gyakran felülírja a szokásjog (például Ellickson [1991]), a szerződéses ígéretek érvényesíthetösége sokszor nagyobb mértékben függ a személyes jellegü garanciáktól, mint a jogrendtől (Bernstein [1992], McMillan-Woodruff [2000]). Másrészt a formális szabályt értelmező, alkalmazó, szankcionáló szervezetek (hatóság, bíróság, rendőrség) jelentősen befolyásolják, miként érvényesül de facto a szabály. Például ugyanaz a jogszabály, amely formálisan a kisebbségi részvényeseket védi, egyes országokban valóban ezt a formális célt szolgálja, más országokban gyakorlatilag nem használják, megint máshol pedig a kormányzat a nagyvállalatok többségi tulajdonosainak kisemmizésére használja fel (Milhaupt-Pistor [2008]). Az intézményépítés valódi kérdése mindig az, hogy lehet-e változtatni a befolyásolni kívánt gazdasági szereplők ténylegesen érzékelt ösztönzőin, s ha igen, milyen eszközökkel. 
2. A transzPlantáció KORlátai • Új intézményeket kitalálni nehéz, teljesen újakat szinte lehetetlen. Természetes jelenség ezért az intézmények átvétele, transzplantációja. Bár La Porta és szerzőtársai [1997] nyomán az átültetést sokszor a gyarmati vagy fejlődő országokhoz kapcsolják, valójában az Európán belüli jogfejlődés is a mai napig az átvételek-átadások hosszú folyamataként jellemezhetö (Berkowitz-Pistor-Richard [2003]). A kérdés tehát nem az, hogy átvegyünk-e, vagy sem, hanem az, hogy mit és hogyan. Az irodalomban körvonalazódó tanulságok a következők: az intézményi átvétel sikere akkor valószínü, ha 1. az a meglévő intézményi rendet csak marginálisan módosítja és illeszkedik annak többi, változatlan eleméhez; 2. az intézményt körültekintően adaptálják a helyi körülményekhez és 3. a helybeliek rendelkeznek előzetes tudással (például jogi hagyománnyal), ami segít értelmezni és a gyakorlatban alkalmazni az új intézményt (Berkowitz-PistorRichard [2003], Boettke-Coyne-Leeson [2008]).

3. Az ENDOGÉN SZABÁLYOK TÚlSÚlYÁNAK ELFOGADÁSA • Még ha egyszerre sok formális szabály is változik, az intézményi rend nagyobb része változatlan marad. Így bármikor is tekintünk egy társadalomra, annak intézményei túlnyomóan endogén történeti folyamatok eredményei. Ez különösen igaz a társadalmi normák, szokások, erkölcsi szabályok lassan változó körére (Williamson [2000]). De igaz a jogrend és a kormányzat fejlődésére is. A polgári jogi igazságszolgáltatás intézményes hagyománya Kelet-Közép-Európában a kommunizmus évtizedeit átvészelve gyorsan erőre kapott, míg Oroszországban a hasonló hagyomány hiánya máig jelentős intézményi ürt jelent (Pistor-Raiser-Geifer [2000]). A decentralizált kormányzás kínai intézményi hagyománya a 20. század minden történelmi drámáját túlélte (Coase-Wang [2012]). A muzulmán országok évszázadokig nem tudták átvenni a jogi személyiség fogalmát, ami a modern gazdaság kialakításának egyik alapvető intézményi eleme lett volna (Kuran [2012]). És még számos példát hozhatnánk. Mindez arra int, hogy tárjuk fel, a történetileg adott, robusztus intézmények, intézményi elemek közül melyek támogathatják a munkamegosztáson alapuló kooperációt, s ezekre építsünk.

4. A PÁRHUZAMOS KÍSÉRLETEZÉS LEHETŐVÉ TÉTELE • Minden intézményi kísérlet időigényes, és ha egyszerre csak egy kísérlet zajlik, akkor lassan találjuk meg a megoldást. Érdemes a hasonló országok kísérleteire figyelnünk (Kerber-Budzinski [2003]). Az intézményi kísérletek számát azonban egy országon belül is megsokszorozhatjuk, ha decentralizáljuk a szabályalkotási hatásköröket, illetve autonómiát biztosítunk az önszerveződésen, önigazgatáson alapuló intézményi kísérleteknek (Ostrom [2005]). Ha a formális jogszabályalkotás és -alkalmazás nyitott a gazdaságban kialakuló normák, gyakorlat figyelembevételére, az szintén támogató keretet adhat a gazdasági szereplők körében folyó spontán intézményi kísérletekhez (Cooter [1994]).

5. AZ ÖNKIKÉNYSZERÍTŐ EGYENSÚLY KIALAKÍTÁSA • Az intézményi rendnek saját magán belül kell biztosítania azokat a motivációkat, amelyek a társadalmi szereplöket a játékszabályok betartására ösztönzik. Végső soron nem hivatkozhatunk valamilyen külső szereplőre, hiszen egy kormányzati szervezet vagy bíróság maga is része a rendnek. Ebben az értelemben minden stabil intézményi rend önkikényszeritö egyensúlyt képez (Aoki [2007], Greif [2006] 55-152. o.). Ha müködőképessé akarunk tenni egy játékszabályt, azt kell elérnünk, hogy a betartása minden érintettnek 
(többé-kevésbé) érdekében álljon, feltéve, hogy a többi szereplő is betartja azt. ${ }^{11} \mathrm{Az}$ intézményi reformok kudarcának gyakori oka, hogy nem veszik figyelembe egy ilyen egyensúly kialakításának feltételeit. Két feltétel (az elosztási konfliktusok kezelése és a hiteles elköteleződés elősegítése) különösen gyakran okoz problémát.

a) Az elosztási konfliktusok kezelése. A szabályok változása mindig változtat az érintettek jóléti helyzetén, és vitára ad okot, hogy a változásból fakadó többleten hogyan osztozzanak meg a különböző csoportok. Ha valamely csoport elégedetlen a neki jutó többlettel (vagy éppen veszteséggel), és módjában áll megakadályozni a változást, vagy szabotálni annak alkalmazását, akkor azt meg fogja tenni. A disztribúciós konfliktusok az intézményi reformok talán leggyakoribb gátjai (Rodrik [1996], Ogilvie-Carus [2014]).

b) A hiteles elköteleződés elösegitése. Még ha sikerül is megállapodni a többlet elosztásában, akkor is kérdés, hogy a felek betartják-e ígéreteiket. A legnagyobb nehézséget az ígéretek melletti hiteles elköteleződés jelenti (North-Weingast [1989], Greif [2006] 91-123. o., Dixit [2003]). Hogyan képes egy kormányzat hitelesen megígérni az állampolgároknak, hogy nem vet ki magas adót, miután lehetőséget kap a vagyonuk felmérésére? Hogyan képes egy hivatalnok biztosítani a politikust, hogy nem él vissza a neki adott függetlenséggel? Vagy egy szabályozni kívánt iparág szereplői, hogy ellenőrzés nélkül is betartják az etikai kódexüket? Amíg az ígéret nem hiteles, a másik fél nem fogja elfogadni, és a megállapodás kútba esik. Az ígéret hitelét az adhatja, ha a megszegő fél ígéretének be nem tartása esetén szankcióval szembesül. A politikai életben a szankciók fontos forrása egyrészt a jó hírnév és vele együtt a jövőbeli kooperációs lehetőségek elvesztése, másrészt a hatalmi egyensúly, amely szankcionálási lehetőséget ad a sértett fél kezébe.

\section{Tanulságok a magyar gazdaságfejlődés számára}

Ha elfogadjuk azt a coase-i értelmezést, hogy a kapitalizmus az önkéntes cserekapcsolatokban formát öltő kooperációt támogató intézményi rend, akkor nincs más ismert útja a gazdasági fejlődésnek, mint az - így értett - kapitalizmus fenntartása, javítása. Az alternatíváknak - a tervutasításnak vagy az önfenntartó gazdálkodásnak - tulajdoníthatunk bizonyos előnyöket, de hogy gazdasági prosperitást nem hoznak, abban nem kételkedhetünk. Ami a kelet-ázsiai országokban, köztük Kínában történik, az a kapitalizmus intézményi alapelvének meghonosítása, az intézményi részletek helyi körülményekhez igazításával, illetve spontán igazodásával (Coase-Wang [2012]).

Ha elfogadjuk, hogy az intézményi rend minden országban jelentős részben endogén, történetileg adott és nehezen javítható, akkor az is világos, hogy nem igazán tehetünk mást, mint hogy ebben az értelemben csak kelet-közép-európai, azon belül is magyarországi kapitalizmust építgethetünk, módosítgathatunk. A történelmi árnyékunkat nem lehet átugrani, bárhonnan máshonnan merítünk is intézményi ötleteket.

A magyar gazdaságot a prosperitás irányába tehát azok a változások viszik, amelyek elösegítik az önkéntes, kölcsönösen elönyös csere mint kooperációs forma terjedését.

\footnotetext{
${ }^{11}$ Vagyis Nash-egyensúlyt kell kialakítanunk.
} 
Ennek elfogadása jelentős szemléletbeli váltást igényel: a verseny helyett az együttműködést állítja előtérbe. A verseny természetesen fontos, de az együttmüködés szabadságának következményeként értelmezendő (vö. Szalai-Szepesi [2009]). E szemlélet terjedése egyrészt talán változtathat a kapitalizmus igen negatív közmegítélésén, és növelheti a kapitalizmust kibontakoztató intézményi változások elfogadottságát. Pszichológusok vizsgálataiból (Fülöp-Roland-Levy [2004], Sebestyén-Fülöp [2015]) tudjuk, hogy a magyar fiatalok nemzetközi összehasonlításban rendkívül negatív képzeteket társítanak a verseny és a versengés fogalmához. Ha a kapitalizmusban az együttmüködést is észrevesszük, a gazdasági rend egyoldalúan negatív megítélése is oldódhat. ${ }^{12}$ Még fontosabb, hogy a közgazdászok figyelmét új irányba: a kooperációt gátló és támogató tényezők vizsgálata felé tereli.

Coase a legfontosabb ilyen tényezőkként azokat az intézményeket, azaz társadalmi játékszabályokat azonosította, amelyek a tulajdonviszonyokat és a szerződéses kapcsolatokat szabályozzák. Ezek elemzése és javítása az alapvető közgazdasági kihívás. A szóban forgó intézmények jelentős része nem állami, hanem magáneredetű. A vállalatok, munkaviszonyok, üzleti kapcsolatok, többé-kevésbé formalizált önszabályozó hálózatok játékszabályainak javulása legalább olyan fontos, mint a formális jogrendé.

Az intézmények javítása kísérletező tevékenység, amely sok „,barkácsolást”, improvizációt is igényel. Mindazonáltal azonosíthatók olyan „tervezési alapelvek”, amelyek orientálhatják az intézményépítés folyamatát, így a de jure és de facto szabályok megkülönböztetése, az intézményi átvétel korlátainak figyelembevétele, a párhuzamos kísérletezés ösztönzése, az intézmények önkikényszerítő egyensúlyként való kialakítása.

De a legfontosabb tervezési elv talán a történetileg adott, endogén intézmények mindenkori túlsúlyának elfogadása. Ebböl az is következik, hogy nagyon jól meg kell értenünk azt a megörökölt intézményi rendet, amelyben jelenleg élünk, $s$ amelyen apránként javítani akarunk. Mely elemei támogatják a kapitalista kooperációt, s melyek nem? Melyek változtathatók ezek közül könnyen, s melyek nem? Minderről még mindig igen keveset tudunk (vö. Szalai-Szepesi [2009]). Ahhoz, hogy világosabban lássuk, hová juthatunk el, mindenekelőtt azt kellene jobban látnunk, hogy honnan is indulunk.

\section{Hivatkozások}

Acemoglu, D.-Robinson, J. A. [2013]: Miért buknak el nemzetek? A hatalom, a jólét és a szegénység eredete. HVG Könyvek. HVG Kiadói Rt., Budapest. http://dx.doi.org/10.1556/ tarskut.32.2014.2.7.

AoKI, M. [2007]: Endogenizing Institutions and Institutional Changes. Journal of Institutional Economics, Vol. 3. No. 1. 1-31. o. http://dx.doi.org/10.1017/s1744137406000531.

BARZeL, Y. [1997]: Economic Analysis of Property Rights. Cambridge University Press, New York. http://dx.doi.org/10.1017/cbo9780511609398.

\footnotetext{
${ }^{12}$ Nemrégiben Rubin [2014] a Southern Economic Association elnöki székfoglaló beszédében ezt a szemléletváltást részben retorikai okokból ajánlotta az amerikai közgazdászok figyelmébe, mondván, hogy honfitársai(!) „emporiofóbiában”, „piacfélelemben” szenvednek, mert annak lényegét - tévesen a versenyben látják.
} 
Bates, R. H. [1988]: Contra Contractarianism: Some Reflections on the New Institutionalism. Politics and Society, Vol. 16. No. 6.387-401. o. http://dx.doi.org/10.1177/ 003232928801600207.

Berger, P. L. [1992]: A kapitalista forradalom. Gondolat, Budapest.

Berkowitz, D.-Pistor, K.-Richard, J.-F. [2003]: The Transplant Effect. American Journal of Comparative Law, Vol. 51. No. 1. 163-203. o. http://dx.doi.org/10.2307/3649143.

Bernstein, L. [1992]: Opting out of the Legal System: Extralegal Contractual Relations in the Diamond Industry. Journal of Legal Studies, Vol. 21. No. 1. 115-157. o. http://dx.doi. org/10.1086/467902.

Bod Péter Áxos [2011]: The Unloved Hungarian Capitalism. Hungarian Review, 4. 24-35. o.

Boettke, P. J.-Coyne, C. J.-Leeson, P. T. [2008]: Institutional Stickiness and the New Development Economics. American Journal of Economics and Sociology, Vol. 67. No. 2. 331-358. o. http://dx.doi.org/10.1111/j.1536-7150.2008.00573.x.

Bohle, D.-Greskovits BéLa [2012]: Capitalist Diversity on Europe's Periphery. Cornell University Press, Ithaca/London.

Brennan, G.-Buchanan, J. M. [1985]: The Reason of Rules: Constitutional Political Economy. Cambridge University Press, Cambridge. http://dx.doi.org/10.1017/cbo9780511895937.

Brousseau, E.-Glachant, J.-M. [2008]: New Institutional Economics: A Guidebook. Cambridge University Press, Cambridge. http://dx.doi.org/10.1017/cbo9780511754043.

Buchanan, J. M. [1964]: What Should Economists Do? Southern Economic Journal, Vol. 30. No. 3. 213-222. o. http://dx.doi.org/10.2307/1055931.

Calabresi, G.-Melamed, A. D. [1972]: Property Rules, Liability Rules, and Inalienability: One View of the Cathedral. Harvard Law Review, Vol. 85. No. 6. 1089-1128. o. http:// dx.doi.org/10.2307/1340059.

Cheung, S. N. S. [1983]: The Contractual Nature of the Firm. Journal of Law and Economics, Vol. 26. No. 1. 1-21. o. http://dx.doi.org/10.1086/467023.

Coase, R. H. [1937/2004]: A vállalat természete. Megjelent: Coase [1988/2004] 53-83. o. Angolul: The Nature of the Firm. Economica, Vol. 4. (1937) No. 16. 386-405. o. http:// dx.doi.org/10.2307/2626876.

CoAse, R. H. [1959]: The Federal Communications Commission. Journal of Law and Economics, 2. 1-40. o. http://dx.doi.org/10.1086/466549.

Coase, R. H. [1960/2004]: A társadalmi költség problémája. Megjelent: Coase [1988/2004] 137-214. o. Angolul: The Problem of Social Cost. Journal of Law and Economics, 3. (1960) 1-44. o. http://dx.doi.org/10.1086/466560.

CoAse, R. H. [1974/2004]: A világítótorony a közgazdaságtanban. Megjelent: Coase [1988/2004] 255-290. o. Angolul: The Lighthouse in Economics. Journal of Law and Economics, Vol. 17. (1974) No. 2. 357-376. o. http://dx.doi.org/10.1086/466796.

CoAse, R. H. [1977]: The Wealth of Nations. Economic Inquiry, Vol. 15. No. 3. 309-325. o. http://dx.doi.org/10.1111/j.1465-7295.1977.tb00478.x.

CoAse, R. H. [1988/2004]: A vállalat, a piac és a jog. Nemzeti Tankönyvkiadó, Budapest. Angolul: The Firm, the Market and the Law. University of Chicago Press, Chicago-London, 1988. http://dx.doi.org/10.7208/chicago/9780226051208.001.0001.

CoAsE, R. H. [1992]: The Institutional Structure of Production. American Economic Review, Vol. 82. No. 4. 713-719. o. http://www.jstor.org/stable/2117340.

CoAse, R. H. [1997]: Interview with Ronald Coase. Inaugural Conference. International Society for New Institutional Economics. St. Louis, Missouri. https://www.coase.org/ coaseinterview.htm. 
Coase, R.-WAng, N. [ 2012]: How China Became Capitalist. Palgrave Macmillan, New York. $10.1057 / 9781137019370$.

Cooter, R. D. [1994]: Structural Adjudication and the New Law Merchant: A Model of Decentralized Law. International Review of Law and Economics, Vol. 14. No. 2. 215-231. o. http://dx.doi.org/10.1016/0144-8188(94)90020-5.

Cooter, R. D.-Ulen, T. [2005]: Jog és közgazdaságtan. Nemzeti Tankönyvkiadó, Budapest. CsABA LÁszló [2006]: A fölemelkedő Európa. Akadémiai Kiadó, Budapest.

CsABA LÁszLó [2011]: A magyar átalakulás és fejlődés néhány általánosítható elméleti tanulsága. Közgazdasági Szemle, 58. évf. 10. sz. 813-831. o.

Csillag Tamás-Szelényi Iván [2015]: Drifting from Liberal Democracy. Neo-Conservative Ideology of Managed Illiberal Democratic Capitalism in Post-Communist Europe. Intersections. East European Journal of Society and Politics, Vol. 1. No. 1. 18-48. o. http:// dx.doi.org/10.17356/ieejsp.vli1.28.

Demsetz, H. [1967]: Toward a Theory of Property Rights. American Economic Review, Vol. 57. No. 2. 347-359. o.

Dixit, A. [2003]: Some Lessons from Transaction-Cost Politics for Less-Developed Countries. Economics and Politics, Vol. 2. No. 15. 105-133. o. http://dx.doi.org/10.1111/14680343.00118 .

Ellickson, R. C. [1991]: Order Without Law: How Neighbors Settle Disputes. Harvard University Press, Cambridge, Mass. .

Fertő Imre-Bakucs Lajos Zoltán-Elek SÁndor-Forgács Csaba [2012]: A szerződések teljesülése a magyar élelmiszerláncban. Közgazdasági Szemle, 59. évf. 1. sz. 63-73. o.

Fülöp Márta-Roland-Levy, C. 2004]: The Perception of Economic Competition among French and Hungarian Secondary School Students. XXVIII. International Congress of Psychology. Peking, augusztus 8-13.

Goldberg, V. P. [1980]: Relational Exchange: Economics and Complex Contracts. American Behavioral Scientist, Vol. 23. No. 1. 337-352. o. http://dx.doi.org/10.1177/ 000276428002300304.

Greif, A. [2005]: Commitment, Coercion, and Markets: The Nature and Dynamics of Institutions Supporting Exchange. Megjelent: Menard, C.-Shirley, Mary M. (szerk.): Handbook of New Institutional Economics. Springer, 727-786. o. http://dx.doi. org/10.1007/b106770.

Greif, A. [2006]: Institutions and the Path to the Modern Economy: Lessons from Medieval Trade. Cambridge University Press. http://dx.doi.org/10.1017/cbo9780511791307.

Hámori Balázs-Derecskei Anita-Hurta Hilda-Szabó Katalin-Tóth László [2007]: Versengő és kooperatív magatartás az átalakuló gazdaságban. Közgazdasági Szemle, 54. évf. 6. sz. 579-601. o.

Hayeк, F. A. [1982]: Law, Legislation, Liberty. Routledge and Kegan Paul, London. http:// dx.doi.org/10.4324/9781315887685.

HAYек, F. A [1991]: A végzetes önhittség. A szocializmus tévedései. Közgazdasági és Jogi Könyvkiadó, Budapest.

Hermalin, B. E.-Katz, A. W.-Craswell, R. [2007]: Contract Law. Megjelent: Polinsky, A. M.-Shavell, S. (szerk.): Handbook of Law and Economics. North Holland.

Hough, J. F.-Grier, R. [2015]: The Long Process of Development. Cambridge University Press, Cambridge. http://dx.doi.org/10.1017/cbo9781107479838.

KapÁs Judit [2003]: A piac mint intézmény - szélesebb perspektívában. Közgazdasági Szemle, 50. évf. 12. sz. 1076-1094. o. 
Kerber, W.-Budzinski, O. [2003]: Towards a Differentiated Analysis of Competition of Competition Laws. ZWeR-Journal of Competition Law, Vol. 1. No. 4. 411-448. o. http:// dx.doi.org/10.15375/zwer-2003-0402.

Kornai János [1999]: A rendszerparadigma. Fogalmi tisztázás. Közgazdasági Szemle, 46. évf. 7-8. sz. 585-599. o.

KoRNAI JánOs [2000]: Tíz évvel a Röpirat angol kiadásának megjelenése után. Közgazdasági Szemle, 47. évf. 9. sz. 647-661. o. .

Kornai János-Rose-Ackerman, S.-Rothstein, B. (szerk.) [2006]: Tisztesség és bizalom a posztszocialista átmenet fényében. Nemzeti Tankönyvkiadó, Budapest.

Kuran, T. [2012]: The Long Divergence: How Islamic Law Held Back the Middle East. Princeton University Press, Princeton. http://dx.doi.org/10.1515/9781400836017.

La Porta, R.-Lopez-De-Silanes, F.-Shleifer A.-Vishny. R. W. [1997]: Legal Determinants of External Finance. The Journal of Finance, Vol. 52. No. 3. 1131-1150. o. http://dx.doi. org/10.2307/2329518.

McMillan, J.-Woodruff, C. [2000]: Private Order under Dysfunctional Public Order. Michigan Law Review, Vol. 98. No. 8. 2421-2458. o. http://dx.doi.org/10.2307/1290349.

MÉnard, C.-Shirley, M. M. (szerk.) [2005]: Handbook of New Institutional Economics. Springer, Berlin-Heidelberg. http://dx.doi.org/10.1007/b106770.

Mike Károly [2014]: Ronald Coase - itt és most. Közgazdasági Szemle, 61. évf. 3. sz. 315-323. o.

Milhaupt, C. J.-PIstor, K. [2008]: Law \& Capitalism: What Corporate Crises Reveal about Legal Systems and Economic Development around the World. University of Chicago Press, Chicago-London.

Muraközy LÁszló (szerk.) [2012]: A bizalmatlanság hálójában. A magyar beteg. Corvina, Budapest.

MuRAKözy LÁszló [2008]: Magyarország felemelkedése és hanyatlása. Közgazdasági Szemle, 55. évf. 2. sz. 149-168. o.

Murrell, P. [2005]: Institutions and Firms in Transition Economies. Megjelent: Menard, C.Shirley, M. M. (szerk.). Handbook of New Institutional Economics. Springer, 667-699. o. http://dx.doi.org/10.1007/b106770.

North, D. C. [1990]: Institutions, Institutional Change and Economic Performance. Cambridge University Press, Cambridge.

North, D. C.-Weingast, B. R. [1989]: Constitutions and Commitment: The Evolution of Institutions Governing Public Choice in Seventeenth-Century England. Journal of Economic History, Vol. 49. No. 04. 803-832. o. http://dx.doi.org/10.1017/s0022050700009451.

North, D. C.-Weingast, B. R.-Wallis, J. J. [2009]: Violence and Social Orders: A Conceptual Framework for Interpreting Recorded Human History. Cambridge University Press, Cambridge. http://dx.doi.org/10.1017/cbo9780511575839.

Nölke, A.-Vliegenthart, A. [2009]: Enlarging the Varieties of Capitalism: The Emergence of Dependent Market Economies in East Central Europe. World Politics, Vol. 61. No. 04. 670-702. o. http://dx.doi.org/10.1017/s0043887109990098.

Ogilvie, S.-Carus, A. W. [2014]: Institutions and Economic Growth in Historical Perspective. Megjelent: Aghion, P.-Durlauf, S. (szerk.): Handbook of Economic Growth, Vol. 2A, Elsevier, 403-513. o. http://dx.doi.org/10.1016/B978-0-444-53538-2.00008-3.

Ostrom, E. [1990]: Governing the Commons. Cambridge University Press, Cambridge. http://dx.doi.org/10.1017/cbo9780511807763.

Ostrom, E. [2005]: Understanding Institutional Diversity. Princeton University Press, Princeton. 
PARISI, F.-Rowley, C. K. [2005]: The Origins of Law and Economics. Essays by the Founding Fathers. The Locke Institute, Edward Elgar, Cheltenham, UK-Northampton, MA.

PEW [2009]: Two Decades After the Wall's Fall. End of Communism Cheered but Now with More Reservations. Global Attitude Survey, Pew Global Attitudes Project, Washington, D.C. http://www.pewglobal.org/files/pdf/267.pdf.

Pistor, K.-Raiser, M.-Geifer, S. [2000]: Law and Finance in Transition Economies. Economics of Transition, Vol. 8. No. 2. 325-368. o. http://dx.doi.org/10.1111/14680351.00047.

RoDrik, D. [1996]: Understanding Economic Policy Reform. Journal of Economic Literature, Vol. 34. No. 1. 9-41. o. http://www.jstor.org/stable/2729408.

RoDRIK, D. [2006]: Goodbye Washington Consensus, Hello Washington Confusion? A Review of the World Bank's Economic Growth in the 1990s: Learning from a Decade of Reform. Journal of Economic Literature, Vol. 44. 4. 973-987. o. http://dx.doi.org/10.1257/jel.44.4.973.

Rubin, P. H. [2014]: Emporiophobia (Fear of Markets): Cooperation or Competition? Southern Economic Journal, Vol. 80. No. 4. 875-889. o. http://dx.doi.org/10.4284/0038-40382013.287.

SACHS, J. D.-Woo, W. T. [2001]: Understanding China's Economic Performance. Journal of Policy Reform, Vol. 4. No. 1. 1-50. o. http://dx.doi.org/10.1080/13841280008523412.

SEBESTYÉN NóRA-FÜLÖP MÁRTA [2015]: A versengés, győzelem és vesztés szubjektív jelentése magyar, kínai és Magyarországon tanuló kínai diákok körében. Magyar Pszichológiai Szemle, 70. évf. 1. sz. 143-158. o. http://dx.doi.org/10.1556/0016.2015.70.1.9.

Szalai Ákos (szerk.) [2009]: Kapitalista elvárások. Közjó és Kapitalizmus Intézet, Budapest.

Szalai Ákos (szerk.) [2010]: Jelentés a magyarországi kapitalizmus állapotáról, 2009. Közjó és Kapitalizmus Intézet, Budapest.

SzALAi Ákos (szerk.). [2011]: Jelentés a magyarországi kapitalizmus állapotáról, 2010. Közjó és Kapitalizmus Intézet, Budapest.

Szalai Ákos [2013]: A magyar szerződési jog gazdasági elemzése. Széchenyi István Szakkollégium-L'Harmattan, Budapest.

Szalai Ákos-Szepesi Balázs [2009]: Mit nem tudunk a magyar kapitalizmusról? Megjelent: Szepesi [2009] 66-68. o.

Szamuely LÁszló-Csaba LÁszló [1998]: Rendszerváltozás a közgazdaságtanban - közgazdaságtan a rendszerváltozásban. Közgazdasági Szemle Alapítvány, Budapest.

SzÉKELY-DoBy ANDRÁs [2014]: A kínai reformfolyamat politikai gazdaságtani logikája. Közgazdasági Szemle, 61. évf. 12. sz. 1397-1418. o.

SzEPEsi BALÁzs (szerk.) [2009]: Jelentés a magyarországi kapitalizmus állapotáról, 2008. Közjó és Kapitalizmus Intézet, Budapest.

Tóth István György [2009]: Bizalomhiány, normazavarok, igazságtalanságérzet és paternalizmus a magyar társadalom értékszerkezetében. A gazdasági felemelkedés társadalmikulturális feltételei címü kutatás zárójelentése. Tárki. http://www.tarki.hu/hu/research/ gazdkult/gazdkult_elemzeszaro_toth.pdf.

Williamson, O. E. [1975]: Markets and Hierarchies. Analysis and Antitrust Implications. Free Press, New York.

Williamson, O. E. [1985]: The Economic Intstitutions of Capitalism. Free Press, New York. Williamson, O. E. [2000]: The New Institutional Economics: Taking Stock, Looking Ahead. Journal of Economic Literature, Vol. 38. No. 3.595-613. o. http://dx.doi.org/10.1257/jel.38.3.595. Xu, C. [2011]: The Fundamental Institutions of China's Reforms and Development. Journal of Economic Literature, Vol. 49. No. 4. 1076-1151. o. http://dx.doi.org/10.1257/jel.49.4.1076. 